\title{
The Saint and the Genius
}

\section{Florea Ştefan}

Faculty of Theology and Educational Sciences, Valahia University of Targovişte, Targoviste, Romania

Email: pr_floreastefan@yahoo.com

How to cite this paper: Ştefan, F. (2017) The Saint and the Genius. Open Access Library Journal, 4: e3305.

http://dx.doi.org/10.4236/oalib.1103305

Received: December 15, 2016

Accepted: January 16, 2017

Published: January 19, 2017

Copyright $\odot 2017$ by author and Open Access Library Inc.

This work is licensed under the Creative Commons Attribution International License (CC BY 4.0).

http://creativecommons.org/licenses/by/4.0/

\begin{abstract}
The main purpose of our study is to underline the manifestations of the two mentioned existential realities, embodied in the "saint" and the "genius". We used the method of comparison to make a parallel between the path to perfection, the sanctity, and the one of the genius, namely the creative capacity of sense and value in human nature. Therefore, according to this comparison, we structured our research into three distinct and complementary parts. The first refers to the saint who takes the path of spiritual life, abandon of profane human world and the self and ascension towards God. He accomplishes the way of the calling to perfection, where nature in collaboration with the divine grace delivers itself in the sense given to it in the creation, namely in the full actualization of the image. The second part refers to the path taken by the genius, who comprises the metamorphosis of meanings that are able to give creative coherence to the human nature. The essence of our research is comprised in the comparison of the two (the third part): The experience of holiness and the experience of genius are two realities whose way of manifestation has to do with the given of the human condition.
\end{abstract}

\section{Subject Areas}

Philosophy

\section{Keywords}

Genius, Saint, Eternity, Purification, Spiritual Participation

\section{Introduction}

The saint and the genius are two individualities whose existence stands apart from the immediate, from the altered meanings of living, to get situated in the structures-beyond our understanding-of the creativity on the realm of value. Each of them receives a new existence, the first focusing on the gathering of all the powers of the soul and on their concentration in the name of the Savior, pursues the aware realization of the union with Christ, which is why his work is 
Christocentric, while the second, getting out of the circle of the common realities of life, situates himself in the creative dimension, activating more than the other people the powers given to him by the creation. Nevertheless, the paths they choose, is different in essence, and our purpose is to make an exhaustive comparison between them.

\section{The Saint-The Man Who Understood Christ's Calling}

The commandment of deification addressed to man's freedom must not be understood as a constraint, because man, as a personal being can either accept or reject God's will. On the will to choose, Saint Maximus the Confessor affirmed that it is "the natural force turned towards what is in harmony with nature, a force embracing all the essential properties of nature" [1].

More precisely, according to the same patristic writer, who distinguishes between natural will-namely the desire of acquiring goodness-and the will that chooses and which belongs to the person, nature is the one that wants and acts, yet the person is the one that chooses [1]. It is obvious that the human person is always faced with the freedom of choice, always stumbling towards the way of spiritual advancement. The calling made by God, namely to actualize the image received by the creation, often remains without an answer from man, because man, although he is a person and by this he is intrinsically apt for relation with the Creator, does not reflect and does not act in this sense, namely in the sense of actualizing the purifying relation.

He who has understood the calling addressed to the person, who has activated in Himself the presence of the grace assimilated ontologically by the Mystery of the Holy Baptism and given in the Holy Mysteries of the Church, is the saint. Moreover, he is the man permanently receptive to his Saviour's exhortation: to be perfect as $\mathrm{He}$ is perfect. Our Saviour Christ, the God-Man represents the model, the paradigm worth following. Although the Person of the saint, called to the union with God, is circumscribed to a mutilated nature, haunted by contradictory desires, he knows how to choose what gives greatness to the image given to us, without yelding in front of the instincts of a nature enslaved by sin, turned to concupiscence.

The saint knows that man was made perfect and that "the perfection of our first nature was expressed by man's capacity of getting united with God, of growing increasingly united to the fullness of the divine being, a fullness meant to penetrate and transfigure the created nature" [1]. For this reason, the saint does what a human person ought to do, namely "unite,--according to the words of Saint Maximus-in love, the created nature and the uncreated nature, showing himself in unity and identity, by having acquired grace" [1].

The saint draws close to the ideals of holiness required from mankind on the way shown to him by God, delivering himself from any cyclic conception, namely delivering himself from evil and sin, because his ontological principle is not situated in the bodily existence, but in the existence in Christ. The realization of the existence in Christ will constitute for him a progress from "according 
to the Image" to the image, relativizing the evilness entered in the creation and avoiding the deep abyss of sin [2].

The central feature of his existence according to nature is the potential unity, which man is called to lift, "by the good use of his natural powers" to a perfect unity-realized at present-of him and of the world in God [2]. The saint does his best for his human will to follow the earthly will of God, which was uninterrupted humility, because his human will was giving up continually what was specific to it by nature to receive what was contrary to the human nature: incorruptibility and deification.

Man's healing cannot take place without his return to God willingly and without turning to Him in prayer with our whole faith. This is the attitude of the saint: in total humility, he tries not to lose himself, but to put himself together in uplifting prayer to God.

The holiness of the Christian saint is not similar to other signs of "perfection" specific of the Eastern spiritualities, because the Christian saint understood his master's words. "He understood that one cannot take his cross without self-denial (asceticism). And he also understood that these two merge in an irrevocable imitatio Christi" [3]. For him, the true initiation goes through Christ, and the steps of this initiation go in the sense of the commandment "Be perfect!". By his initiation in Christ he does not become another man, but discovers the ontological dimension of the redeemed being, the meaning of true freedom [3].

When the saint moves away from the crowd, from the intense and stormy daily life, his sense is that of the sacrificer, of the one sacrificing himself willingly, because what interests him is not to waste his life, but to fulfill it. Submission breaks him away from the trifles of nature and he launches himself into a level of existence that his fellows do not understand. It is natural to him not to make idols out of the ephemeral pleasures that the world loves so much. The slavery of the senses presses him, too, proud thoughts tempt him, too, but his vigilant mind stops them. To him, they do not become norms, natural attitudes, as the world sees them-but are disorders of nature that he endeavors to master. He is a paradigm because he shows to the world that it is possible to vibrate in the spirit once you have understood the ephemerity of things. His attitude is not Manicheic. Along with his soul, he also transfigures his body, which he fills with light [3].

To be a saint is ineffable, because holiness is a state reached by patience and after an intense fight against the sinful passions. The state of holiness is translated only by the Word, only He gives it light, only He makes it expressible and reveals its inner coherence. On the wings of grace, the saint preaches to the world the need to awake. And he preaches it praying. The saint is constantly oriented towards love, because love is an orientation and not a spiritual state, an orientation sprung from pondering on Christ's Passions. The road of the saint goes through the difficulties of the world, with the humility of the one who knows that suffering for love draws you close to the Sublime Teacher. "Apart 
from Me, says the Saviour, you can do nothing" (John 15:5). This are words with a resounding echo in the mind of the saint. But, in order to come to Him, the saint loves the creature next to him. And he does not love the creature pragmatically. He does it for love and this is why he reaches a state that cannot be reached by artifices or means that are at hand for anyone, which is possible only by aware (discerning) humility and humble ascension [3].

For the saint, the first stage of his spiritual life is purification by asceticism, which is not a purpose in itself but "a means towards a certain progress pursued" [4], a methodical extension of the spiritual work realized by the baptism. The condition of this purification is renunciation, namely giving up on the world and on oneself. He is part of the category of those who for the sake of perfection, withdraw from the world, choosing to practice the evangelical exhortations: poverty, virginity and submission. If poverty means for a saint total renunciation to the goods of the world, and virginity is at the same time renunciation to the world and to oneself, namely the realization of the angelic life on earth and giving up on the bodily passion, submission is the hardest to realize since it sums up the other two. For the saint, "the eye of the body needs to become the eye of the mind" [4], getting to follow completely Saint Paul the Apostle's words: "I no longer live, but Christ lives in me".

From purification, the saint goes toward illumination, which is a stage of ascent, of progress from what is human to the divine things. Certainly, he realizes the impossibility of reaching this stage by his own personal powers, because for spiritual regeneration, divine help is needed, since a radical purification can be given only by God at the end of his active efforts [4]. In this sense, in Saint John's Ladder (Chapter 22) it is said: "Your body does not belong to you; it is God's; because God gave it to you. Your endeavours, struggles and the effects produced by them, all that is in you, must consequently be referred to God, to things that are essentially His" [4]. In the saint takes place a process of total "disassimilation" of the old man, of assimilation operated by the divine power. Moral virtues such as prudence, justice, force and moderation along with faith, hope and love become in the life of the saint measures of the deified life. In the Saint "the gradual and enthusiastic transformation will be a proportionalization or dilation according to the size of the moral perfection ideal who is our Saviour... a proportionalization possible by the addition of spiritual energy brought by grace... and by the love for God" [4]. The orientation of the saint to the growth of his virtues in God means that the development of the moral personality is possible for he who intensely practices these virtues.

The third direction that the saint pursues is that of the mystical union, namely what the Easterners call $\Theta \varepsilon$ coбı, in the sense of personal participation by grace to the intimate and mysterious life of God [4]. In this way, the Saint begins to live life in Christ, begins a true "theologizing". The saint's withdrawal from the world is not an act of selfishness, is not an act of someone who feels misunderstood, but the act of someone who walks in the ways the Lord has commanded, is the act by which his human body turns into a spiritual body. Moreover, present 
in the world and yet outside it, the saint gives an example of transfiguration, following our Saviour and not himself. Having dedicated all that is his to Christ, "he is running convergently to Mount Tabor, where the miracle of transfiguration occured" [4]. In one word, the aim of the saint's religious life is deification, an aim calling, however, for a preparatory action in agreement to it.

\section{The Genius-The Man Who Chose the Creative Way}

The genius is the man who goes beyond the average of life by far, joining the creative act on a way only he himself chooses, and creating-in this passing world-according to the divine likeness, "with elements taken from this world, the superb simulation of eternity, which is art" [5]. While naturally man is endowed with the aptitude of creating, by virtue of his ontological freedom, he can direct or guide his creation any way he wishes, ignoring the religion in which he is living or the divine grace. And this happens because of the image of God present in him, by which he is given the power, with the help of the spirit, to set in motion his natural aptitudes. Certainly, this image of God, under a state of sin, is not always directed impeccably, so that, due to man's freedom of choice, the human creation can give birth both to idols and to great works [5].

The Holy Fathers often affirm that man's reason is God's throne in the soul, this is why he who has made out of his reason God's throne will know how to dimension-according to his gift-the inexhaustible sides of the human nature given by the creation. From this perspective, the genius is the man who discovered the totality in his image making a selection of values. He knows to deeply listen to the crisis of creation which he is living, and tries to dimension the powers in himself in the sense of rising above the common elements, even if sometimes he can suffer from a crisis of autonomous will, even a Luciferic one [6]. The genius' action comes from his desire to create his own universe, on the one hand, and on the other hand, from the nostalgia of unifying a fragmented cultural creation so that it may show the world its true inner coherence.

The genius is aware of his own finiteness, such an awareness involving the awareness of the Infinite, of what is absolutely limitless [6]. For him, the existence of such a conscience is a "heroic" fact, a sign, a testimony. For this reason, for the true genius, the true knowledge is the one that recognizes [7] the dimension of the existence as creation made by a personal Creator.

"Inside" this creation, the genius would not be himself if he did not have the vision of a world of ideal perfection, a perfection he is always comparing to the world in which he is living and to which he cannot adhere at all [5]. Rarely does a genius renounce the world out of moral considerations. His renunciation is not an act of will, but one having to do with his visionary structure. He does it naturally, with no moral efforts [5]. When he ponders on the structures of the existence he sees the fall they are in and putting forth all the forces available to him, he tries to organize them. Because of his immeasurable and revolutionary nature, a genius may consume himself and burn without realizing anything valuable in the world [8]. This proves that his whole strain, his whole temerity has to 
do with his visionary structure and not at all with the act of will: it has to do with his creative inadaptation to the world he lives in.

Living in this world, a genius is-according to Schopenhauer-"an overwhelming prevailance of the intellect over the will" [5], his vision on the world often going beyond the power of understanding of his contemporaries. Yet, his inadaptability is not renunciation to the world in the sense of virtue, but is part of his natural structure, inadaptation being compensated by the adhesion of the intellect to the world of ideas. "The genius is great by his detachment and the objectiveness of his spirit. He is a visionary. It is not the will to another world that characterizes him, but the intellectual vision of another world" [5].

Regarding what he lives, the genius can manifest himself depending on his vision on the world, which can be either in harmony with the revealed truth or contrary to it. When the genius starts creating values, the world's significance and meanings acquire a personal note which is sometimes in harmony with the moral law, and at other times in contradiction with it. One cannot compare in the sense of the creation of perennial values, a philosophic genius like Nietzche, tending towards deformation, to a genius like Soloviev, Louis Lavelle or Berdiaev, inclined to situate their words in the sense of the revealed truth. The world of perfection the genius tends to has an absolutely special resonance, because it always follows the direction of his definition of the state of Absolute. If we take a look at the tension in the genius' life, we can find here a heroic metamorphosis, almost a sacrifice dedicated to the idea he supports. The genius does not have the possibility of "obiectivizing himself in the creation of a differentiated culture, because he does not take as his system of reference.

\section{The Genius and the Saint-Two Realities Going beyond the Common State}

It is true that between holiness and brilliance (genius) there can be certain similarities, because both of these directions represent-both of them separatelystates going a lot beyond the human condition. They are supranormal occurrences, their essence consisting in an excess of spiritual powers that lead to transfiguration. This is why both brilliance and holiness are "maximal fullness or perfections of beauty and of the moral goods", remaining "profoundly human in their essence", because "the genius is the maximal measure of the natural life and the saint is the maximal measure of the spiritual life" [5].

The question is whether these two dimensions of the human nature are of the same essence to have the possibility to be thought together. These problems need to be clarified, because, out of an insufficient understanding, one could often take the genius for the saint and the other way round. We know that holiness, by definition, is a specifically Christian state, a state that becomes authentic by the work of the divine grace, while brilliance can appear as a state in the universal human area, therefore also outside the Christianity. Therefore, can we talk about the genius and about the saint using the same terms or must the differences or similarities between them be understood from a totally different perspective? 
It is evident that the action of the genius is rather worldly than spiritual, whereas the action of the saint is of a spiritual order. The genius' work, in the best case, can be accepted and justified by the religious conscience, whereas the holiness of the saint needs no confirmation from the genial conscience, because its construction takes place on a different level than that of the daily values. Speaking about the holiness of Saint Seraphim of Sarov and about the genius of Pushkin, N. Berdiaev made the following observations: "The saint creates himself, he creates another, more perfect existence, in himself. The genius creates great works, does great deeds in the world. Only the creation of self is redeeming. The creation of the great values can destroy. Saint Seraphim created nothing else than himself, and it is only by this that he was transfiguring the world-Pushkin created something great for the world, yet he was not creating himself. In the creation of a genius there is a sort of self-sacrifice. The action of the saint is first of all putting his own good in order. Pushkin was kind of destroying his own soul in his self's genial-creative outbursts. Seraphim was saving his soul by his spiritual action in himself" [8].

On the topic of this idea, Berdiaev has no doubt that in the genius' sacrifice there is another type of holiness in front of God, another religious action, equal in value to canonical holiness. He believes that brilliance can be a religious way similar to holiness, that a genius' entire creation can be called "spiritual", that for the divine purposes, brilliance is just as necessary as holiness. And he formulates this theory starting from the idea that "not all people can be saints, not all people must be saints, not all people are meant by God for holiness" [8]. In a way, Berdiaev thinks that "the religious sign of the genius, as a supreme manifestation of the human creation, remains hidden" even if the whole way of his creative inspiration "remains earthly, secular, unsanctified" [9]. The genius' creation, viewed from the perspective of holiness, ought to be justified positively from a religious perspective. In this sense, "if the genius becomes a poet or a philosopher because the state of sin prevents him from following the only true way, the way of holiness, then he would be condemned by the Christian conscience" [9]. The only manner a genius can follow the way of holiness-according to Berdiaevis to put "the object of creation over himself" to "prefer the truth more than himself" [9].

And yet, with all the genius' heroism, the state he reaches cannot be placed on the same level as holiness, even if holiness and brilliance have as their common aim "to defeat" the world, even if they both tend to a special existence, spiritually perfect.

What is specific of the genius and makes him different from the saint is the renunciation to the world by his visionary structure, which does not have at all the character of a renunciation, because it comes not as a consequence of an effort, but naturally. His renunciation is not what could be called a moral endeavor. The saint differs from the genius by the supreme endeavor of the will to get detached from the things of the world by an overwhelming asceticism. The saint's fight is not the battle of a genius with the structures of a world that does 
not correspond to his visionary horizon, but the fight against the world and against sin. The ascetic's renunciation to the world means renunciation to sin by a war "waged with a strained will, with a matchless moral energy" [5]. The saint is the one who denies the moral corruption of the world he left behind, because initially he participated himself to its corruption. Unlike the saint, the genius is not concerned by the problem of the moral conscience of sin because it is not this that drives him away from the world, but a superior esthetic sense. Thus, one can say that "a genius is an esthetic instinct, separating man from the world. And it is very possible for the genius not to have the conscience of the sin devastating the existence", because "the conscience of sin is specifically Christian, whereas a genius may or may not be Christian" [5].

Often, what has to do with the conscience of the superiority of the genius is pride [5], because he has the feeling that the sense of his creative message is misunderstood by his contemporaries. It is true that the whole creative way of the genius calls for a sacrifice, namely sacrificing and renouncing personal order almost up to the point of spiritual confusion.

It is precisely this aspect of the sacrifice of life for an idea that gives the genius the conscience of his superiority in front of his fellows, a conscience that he feels called to affirm whenever necessary. The pride of his superior dimensions can give birth to the unhappiness of the genius, as a consequence of the fact that he feels misunderstood. An obvious illustration of this is Eminescu's verse: “... while I, within my world, I feel/Immortal and cold". While for the genius, the pride of his creation needs to be affirmed, for the saint it represents the greatest capital sin. He knows that the present state of mankind is a consequence of the sin of selfishness, of the pride desiring to uselessly rise over the self. Affirming yourself, with all its creative baggage, is the conscience of the genius; forgetting about yourself, humbly going beyond it by an uplifting descent, such is the conscience of the saint.

We can agree that the genius' road calls for sacrifice, which, understood on a level of values, cannot be considered any lower than the saint's willingness to sacrifice himself. The case of brilliance just as the case of holiness calls for the abandonment of the world. The genius also calls for sacrificing a sure situation, salvation and the lack of that order specific of the moral personality. Evidently, a special force is needed to meet the visionary demands. Similarly, the way of the saint also represents a way of the heroic act, the way of an effort and of a spiritual force that excludes the underground forces of the sinful existence. Unlike the genius, the saint assures the safety of his own order [8]. While holiness represents the beginning of the joy of living in the sinlessness that can transfigure the world, brilliance represents, from this perspective, the tragic incapacity of dimensioning the world according to one's own visionary molds.

We can understand the genius as the one who did not burry his talent given to him by the creation, as his work has accomplished the vocation to which he was called. Berdiaev affirmed that "the idea of vocation is in its essence a religious 
one, not a "worldly" one and the accomplishment of one's vocation is a religious duty" [8]. It is in this vocation that the core of genius in each man might be found, this vocation meaning a straining of man's entire spirit. And this is how we can understand the nature of the genius as being religious since the accomplishment of the vocation by the multiplication of the talent is a divine commandment. The vocation of the genius can be perceived as another ontology of the human being, as a holy in adaptation to "this world" [8]. The saint does not experience in adaptation to this world, but remains in the world, while being beyond it. Unlike the genius, who by his creation condemns the world to perdition, "because of his incapacity of understanding", the saint understands the world as being altered by sin. This is what his vocation consists in, namely the permanent dimensioning of his efforts to understand the creation's powerlessness to lift itself up from the state of sin. The saint over dimensions naturemore precisely he enters the normality of the Christian ethics-, and fights against the darkness of sin. He is accomplishing the Christian calling of being not just a creator of sublime esthetics as the genius, but also a keeper of the creation by the collaboration with the divine grace. Consequently, one can say that "the saints are more exposed than other people to the power of the evil one because they really know misery, and they know that the world needs to be intolerant to evil" [10]. The genius can be tolerant with evil, with the state of moral disorder of nature. The saint, however, does not understand juridically the need for lack of moral disorder, but considers it an imperative of the human condition. The genius can create moral works, demonstrating a high religious conscience able to dimension creatively the religious conscience of his contemporaries, without having a moral life. Therefore, there can be a contradiction between his work and his life. The saint can create an example in the society, an example of transfiguration, yet his sermon, his teaching can have but one direction, namely to be in harmony with the exemplarity of the life of holiness.

The Saint loves God and his fellow as himself and by this he fully obeys the commandment of love. To go beyond your self, to see in the other another reality equal to yours, means admitting an imperative higher than the pride of self-affirmation, namely that of the humility suffering and loving in God. The genius loves his work more than anything else. He idolizes it-there can be exceptions, too-with an immeasurable idolatry, it becomes the object of his love. If it happens that on this way both God and man show up, then the mixture takes place in a doubtful manner, because talent is the genius' skill to make confusion "become" truth. The genius' life knows no full satisfaction; it "is always tragically at odds with the surrounding world" [8]. For this reason, virtue is a state that is hard to reach in a genius's life; there is a great distance between him and virtue. The genius puts a lot of energy in his work, "seeing himself more in it than in the man in himself" [5].

His creation dominates him; it makes him aware of the power manifested in his work. This is why his satisfaction is also realized "in the thing he creates and which will endure after him" [5]. However, with all his desire of living through 
his work, a genius' masterpiece is eternal only figuratively, because "it lives as long as the matter it was modelled from still exists" [5]. From such a perspective, the genius is the one who gathers riches on earth and his riches resist as long as his creation still exists. It cannot give birth to virtue, because virtue does not mean inefficient consumption in oneself, but deliverance from the pride of the immortal creation in order to accomplish another creation, namely deification by grace.

Opposite to a genius, a saint appears in this sense as a real embodiment of virtue. He is his own moral masterpiece compared to the genius who consumes his being in his work [5]. The saint, participating in the mankind's common search for the nature and for the sense of the existing things, has accepted that man is a being whose true greatness is not in the things of the world but in the fact that he has been given "the commandment to become God" [2]. The saint has shown by his work, which is actually his own life, that "man accomplishes his existence to the extent to which he ascends to God and gets united with Him" [2].

The idea affirmed by Berdiaev that the saint is working himself as his own moral masterpiece is wrong. The saint works in himself the human condition of holiness which is asceticism by exerting the will against itself. The ascetic's denial is activated in the denial of the sin that mutilates the being. Consequently, the saint's withdrawal from the world, from sin, means a terrible fight with himself, with the world's sinful ideas. The saint is not an inadaptable as the genius, but someone isolated from his own thoughts related to the world of sin. The Holy Fathers have called the fight of the saint, of the ascetic against sinful thoughts by the generic name: "invisible war". This can be the work of the man who understood the vanity of the world, yet the access to the state of holiness means the work of the divine grace. For this reason, it is not the saint that creates his own holiness, because the deification of the saint, to call the deified man by the term of saint, is not possible except by grace. For the Christian saint "Jesus Christ is the model after Who and the power by Who the world is created a new, made perfect and rearranged along the line of its transcendental destiny" [5].

On the contrary, a genius has no model in his creative activity. He is his own guide. The "well-founded" of his own argumentations is "founded" in his image on the world. The genius' work on himself unfolds in a world of sin, in the world devoid of God for which the ultimate aim is anthropocentrism. A genius is an autonomous person in the domain of ethics, because he does not leave his self behind, but lifts his self according to his own patterns. The world's model of construction would consist in the world of types built by him. His thoughts are not stopped, like the thoughts of the saint inside "the unseen war", but break free with the passion of one who thinks that what he has to say is everything that there is to be said.

To affirm his ideas, a creative genius is capable of uttering any sentence. Let us imagine Cioran fighting against God's greatness while thinking that he was affirming God from a vision that would have declined His ideal nature. A genius 
creates sin by the words and thoughts said by him, regardless of the consequences of his creative act. For him, the divine grace in the process of human deification is important to a lesser or greater extent. A saint is the creator of his holiness by means of the divine grace, whereas a genius is the creator of his own measure according to which he is trying to articulate the world's fragmented areas.

\section{Conclusions}

Situating holiness and brilliance on the same level is non-sensical, because it would mean choosing for models of moral life, brilliant personalities instead of our Saviour, the Lord's Mother and the Saints. Mistaking holiness for brilliance is accepting an esthetic-imaginary image of immortality instead of the immortality that is real by deification [5].

One must not exclude the fact that a genius can bring to light certain data of the creation by his talent given to him by God. When his work relies on grace, on generosity then the result will be in harmony with these, because "any gift is grace and only what is grace is generosity" [8]. When the vision of the genius agrees with the patterns of the Revelation, his creation can no longer be a simple esthetic fiction, but a symbol of immortality. For this reason, "in all that is great, in all that shines as truth, as good and as beautiful in the natural creations of the human genius, we need to read the mysterious, awesome exhortations of the Logos, who is precisely the world's reason to be" [5]. Naturally, the Orthodoxy grasped the idea that the separate revelations of the Antiquity are signs of the work of the Logos revealed in the creation, which is why the Orthodoxy painted these geniuses, who understood the essence of the Logos, on the external walls of the altars, yet, without confounding them with the Saints.

Both holiness and brilliance (genius) are separate dimensions. The genius is not the saint and inversely "Holiness is the nature of this world purified from sin" [5], by the energy of the divine grace. It is the submissive accomplishment of the Word and the sublime crowning of the human nature. Brilliance is the nature of the world working by itself without becoming the subject of purification. While a genius can be presented as the concretization in the visionary creation of a natural gift, holiness is a supernatural crowning, a crowning reached by a fierce fight with the self containing sinful passions, and the fight is fought with the help of the divine grace, the only one able to transfigure any human effort.

\section{References}

[1] Lossky, V. (1993) Introducere în teologia ortodoxă (Orthodox Theology: An Introduction), Ed. Enciclopedică. Buc.

[2] Nellas, P, (1994) Omul-animal îndumnezeit (Zoon theoumenon). Ed. Deisis. Sibiu.

[3] Nacu, N. (1996) Paradoxul unei existențe (The Paradox of an Existence), in Renaşterea, 7/1996.

[4] Crainic, N. (1993) Sfințenia împlinirea umanului (Holiness, the Accomplishment of 
the Human), Ed. Mitropoliei Moldovei şi Bucovinei. Iaşi.

[5] Crainic, N. (1994) Nostalgia Paradisului (The Nostalgy of Paradise) Ed. Moldova. Iaşi.

[6] Clément, O. (1991) Berdieaev, Un philosophe russe en France. Desclée de Brower. Paris.

[7] Borella., J. (1995) Criza simbolismului religios (The Crisis of Religious Symbolism). Institutul European. Iaşi.

[8] Berdiaev, N. (1992) Sensul Creației (The Meaning of Creation) Humanitas. Buc.

[9] Berdiaev, N. (1996) Spirit şi libertate (Spirit and Freedom). Ed. Paideia.

[10] Weil, S. (1988) Le Pesanteur et la grace. Plon, Paris.

Submit or recommend next manuscript to OALib Journal and we will provide best service for you:

- Publication frequency: Monthly

- 9 subject areas of science, technology and medicine

- Fair and rigorous peer-review system

- Fast publication process

- Article promotion in various social networking sites (LinkedIn, Facebook, Twitter, etc.)

- Maximum dissemination of your research work

Submit Your Paper Online: Click Here to Submit

Or Contact service@oalib.com 